\title{
LISTED COMPANIES AND ENVIRONMENTAL REPORTING
}

\author{
MW Wickramarahchi \\ Department of Accountaricy, University of Sri Jayewardenepura, Nugegoda
}

This paper presents the results of an empirical study undertaken on current practice of physical and social environmental disclosure in annual report of public listed companies in Sri Lanka. Generally listed companies are the largest private sector business organizations of a country. Their activities could effect the physical; and social environment positively as well as negatively. Company managers and accountants pay attention to the recently developed concept of green accounting and environmental reporting. University academics in accounting have commenced contributions to journals in the sub field of accounting and reporting of environmental information. In this article current practice of environmental reporting by listed companies in Sri Lanka is examined and the relationship between the level of environmental disclosure and selected two company characteristics, total value of assets and number of shareholders are statistically testel. Environmental information available in annual reports on company transactions, transformations, events, and environmental factors affecting them are considered as data. A significant variation in disclosure of environmental information is found among the companies. The result of the examination has revealed a highly significant relationship between the value of the total assets and the environmental disclosure. While large companies provide more environme atal information small companies provide lesser amount of such information through the anaual reports. The relationship between the number of shareholders and the environmental disclosure is not statistically significant. Supply of environmental information does ant vary in relation to the number of shareholders of the companies. 